At the same time, drilling can contribute to a number of problems related to obtaining a better understanding of the structure, evolution, and dynamics of the lithosphere. These include problems related to petrochemical and structural evolution of Earth's crust including lithospheric rheology and strength, and the distribution of plate driving forces; and heat and mass transfer through the lithosphere and thermal structure of the crust and upper mantle.

There is a broad consensus that any ICDP to be established should carry out fundamental science covering as broad a spectrum of Earth science research as possible. The program should be proposal-driven and address key questions at optimal geological sites from around the world and should involve drilling and coring at a variety of depths. That is, the program should not be restricted to only deep or shallow drilling, but drilling should be used as required to address the specific problem of interest.

Following the Potsdam meeting, scientific managers from many of the participating countries traveled to Windischeschenbach, the site of the ongoing German deep drilling project (KTB), to consider the establishment of an International Program of Continental Scientific Drilling. The communiqué issued at this meeting contained the following points:

There is an essential role for continental scientific drilling in the solid Earth sciences. Scientific drilling should be an integral part of modern Earth sciences to obtain critical data and test hypotheses in a broad spectrum of scientific disciplines.

Full realization of that role requires a comprehensive intemational program. Problerns to be addressed are global in nature and in importance to society. The international geoscientific community needs to use drilling to deal with problems that span the full range of solid Earth science disciplines throughout the world. Such problems could best be addressed by establishing an international continental drilling program.

It is time to embark on an international continental drilling program. The time is right because of the outstanding scientific and technical achievements of the KTB project, widespread recognition of the importance of scientific drilling in Earth science, and the recent endorsement of coordinated international scientific drilling activities by the Organization of Economic Cooperation and Development. Also, political changes in Eastern Europe offer many new opportunities for scientific collaboration, and developing countries around the world need assistance in Earth science training.

A final meeting report, "Scientific Rationale for Establishment of an International Program of Continental Scientific Drilling," was drafted by the leaders of the thematic groups. The following is a quote from the report: "We live in a geologically complex world which presents the international geoscientific community with tremendous challenges. Earth scientists must play a key role in satisfying society's ever-increasing dependence on natural resources, in reducing its increasing vulnerability to natural hazards, and in finding solutions to problems associated with remediation of existing environmental damage and prevention of additional environmental degradation. At the same time, Earth scientists are motivated by an inexorable need to better understand planet Earth. This report contains the scientific rationale for establishment of an International Continental Drilling Program to enable the international geoscientific community to meet the challenges they face by complementing ongoing field, laboratory and theoretical studies with critical observations. Without such observations substantive scientific progress on many problems of great importance will be essentially impossible."

Copies of this report can be obtained from J. Lauterjung, GeoForschungsZentrum, Telegrafenberg A17, D-14473 Potsdam, Germany; fax: 331-288-1002; e-mail lau@gfz-potsdam.de.-Mark D. Zoback, Stanford University, Stanford, Calif.; and Rolf Emmermann, GeoForschungZentrum, Potsdam, Germany

\section{Baltica-Siberia Connection Challenges Traditional Tectonics}

\section{Notions}

\section{PAGES 461,462}

Despite the large amount of paleomagnetic, paleoclimatic, biogeographic, and tectonic data available, uncertainty still surrounds the paleotectonic evolution of Siberia and its proximity to other continents during the Ordovician to Silurian periods. Much of this uncertainty arises from the fact that paleomagnetic data cannot be adequately assessed.

However, recent Ordovician-Early Silurian paleomagnetic poles from the southern Siberian Platform (Lena River) show that $\mathrm{Si}$ beria was geographically inverted at low southerly latitudes during the Early Ordovician (Figure 1a). The Siberian plate then drifted slowly northward and across the equator at an average paleolatitudinal velocity of $-5-8 \mathrm{~cm} \mathrm{yr}^{-1}$. During Late Ordovician-Early Silurian time, its velocity increased northward.

In view of the paleomagnetic data from $\mathrm{Si}$ beria, coupled with recent paleomagnetic data and geological evidence from Baltica [Torsvik et al., 1992], we propose that Siberia and Baltica formed conjugate margins during Latest Cambrian to Early-Middle Ordovician time (Figures $1 \mathrm{a}$ and $\mathrm{lb}$ ). In this reconstruction, subduction-related changes to mineral assemblages of basaltic composition in Latest Cambrian/Early Ordovician time in the Scandinavian Caledonides oc- curred in an ocean-continent transition zone that was marginal to Baltica but faced northern Siberia rather than Laurentia.

\section{An Alternate View of Early Landmass Positions}

A reconciliation of the paleomagnetic, paleoclimatic, and biogeographic data (Figure 1) indicates that Avalonia and the European Massifs (Armorica) were located close to Gondwana in high southerly latitudes during Early Ordovician times. Laurentia was positioned in equatorial latitudes during most of the Ordovician. Conversely, Baltica was first situated at intermediate southerly latitudes and drifted northward while undergoing rotations [Torsuik et al. 1992], approximately $90^{\circ}$ counterclockwise from Early Ordovician to Middle Silurian times. Avalonia had rifted away from Gondwana by Llanvirn time, while Armorica remained in high latitudes along with Gondwana throughout the Ordovician (Figure lb). The Tornquist Sea, separating Avalonia and Baltica, narrowed gradually during the Ordovician, as indicated by the increasing faunal similarity, whereas faunal bonds between Avalonia and Gondwana declined.

By the end of the Ordovician, the Tornquist Sea between Avalonia and Baltica had closed sufficiently to form Balonia (Figure 1c). Finally, by Early-Middle Silurian times $(-425 \mathrm{Ma})$, Balonia collided with Laurentia, causing the early stages of the Scandian Orogeny (Figure 1d) and closing the intervening part of the Iapetus Ocean.

\section{New Vlew Counters Long-Held Ideas}

The overturned paleo-orientation of Baltica during Early Ordovician time (Figures la and $1 \mathrm{~b}$ ) casts doubt on the traditional concept of orthogonal relationships of Baltica and Laurentia across a single lapetus Ocean throughout the entire period of Caledonide evolution. The Scandinavian Caledonides are essentially complexes that formed in locations other than where they were found [Roberts and Gee, 1985]. Their current configuration is the result of Mid-Late Silurian collisional orogeny (Scandian) and subsequent extensional events.

The lower nappes-sheetlike bodies of solid rock that have moved long distances at low angles over the the underlying rocksconsist of rock types indigenous to Baltica and its miogeoclinal margin. The middle, or Seve Nappe Complex, contains essentially miogeoclinal rocks, but at high metamorphic grade it includes Late Cambrian/Early Ordovician eclogites [Mork et al., 1988]. Eclogite is granular metamorphic rock composed essentially of garnet and pyroxene, but with the bulk of its composition very similar to that of basalt. The higher nappes are marked by ophiolites-mafic and ultramafic igneous rocks-and island arc sequences of essentially Ordovician age [Sturt and Roberts, 1991]. 
Early Caledonian eclogitization, in Tremadoc time, correlates with westward subduction of Baltic continental crust. This subduction event, with inferred arc development locally, was closely followed by uplift and retrogression of the eclogites and plate accretion of Early Ordovician ophiolites [Sturt and Roberts, 1991]. At the highest tectonostratigraphic level, the heterogenous Uppermost Allochthon has been considered to be of probably Laurentian affinity.

\section{Evidence of a Paleo-Ocean Between Baltica and Siberia}

The paleo-orientations and the latitudinal drift-histories for Siberia and Baltica suggest the presence of a paleo-ocean between $\mathrm{Bal}$ tica and Siberia. This contrasts with earlier models that postulate Latest Cambrian to Early Ordovician subduction and Early Ordovician plate accretion between Laurentia and Baltica (lapetus Ocean).

From Mid-Ordovician to Silurian times, Baltica (Balonia) gradually rotated counterclockwise. Such a rotation likely gave rise to a deep-seated, strike-slip fault regime in the narrowing oceanic tract between Baltica and Siberia (Figure lc), and especially between the obliquely converging plates of rotating Baltica and a southward-drifting Laurentia. This developing fault system may have influenced and possibly controlled the generation and ascent of Late Ordovician (Ashgill) calcalkaline granitoids in the Uppermost Allochthon in Norway [Nordgulen, 1993].

This new plate scenario allows for a Siberian source for Late Ordovician sediments in areas of maritime Laurentia and even exotic pebbles in Middle to Upper Ordovician conglomerates [Minsaas and Sturt, 1985] overlying the Lyngen Gabbro in Northern Norway, hitherto of unknown provenance. It also calls into question the traditional correlations of the Latest Proterozoic to Cambrian miogeoclinal and Cambro-Ordovician eugeoclinal assemblages of Baltica and Laurentia, where plate tectonic reconstructions have been made between essentially "static" nonrotational continental blocks.- $T$. H. Torsvik, Department of Geological Sciences, University of Michigan, Ann Arbor, and NGU, Trondheim, Norway; D. Roberts, and B. A. Sturt, NGU, Trondheim, Norway

\section{References}

Minsaas, O., and B. A. Sturt, The OrdovicianSilurian clastics sequence overlying the Lyngen Gabbro Complex, and its environmental significance, in The Caledonide Orogen-Scandinavia and Related Areas, edited

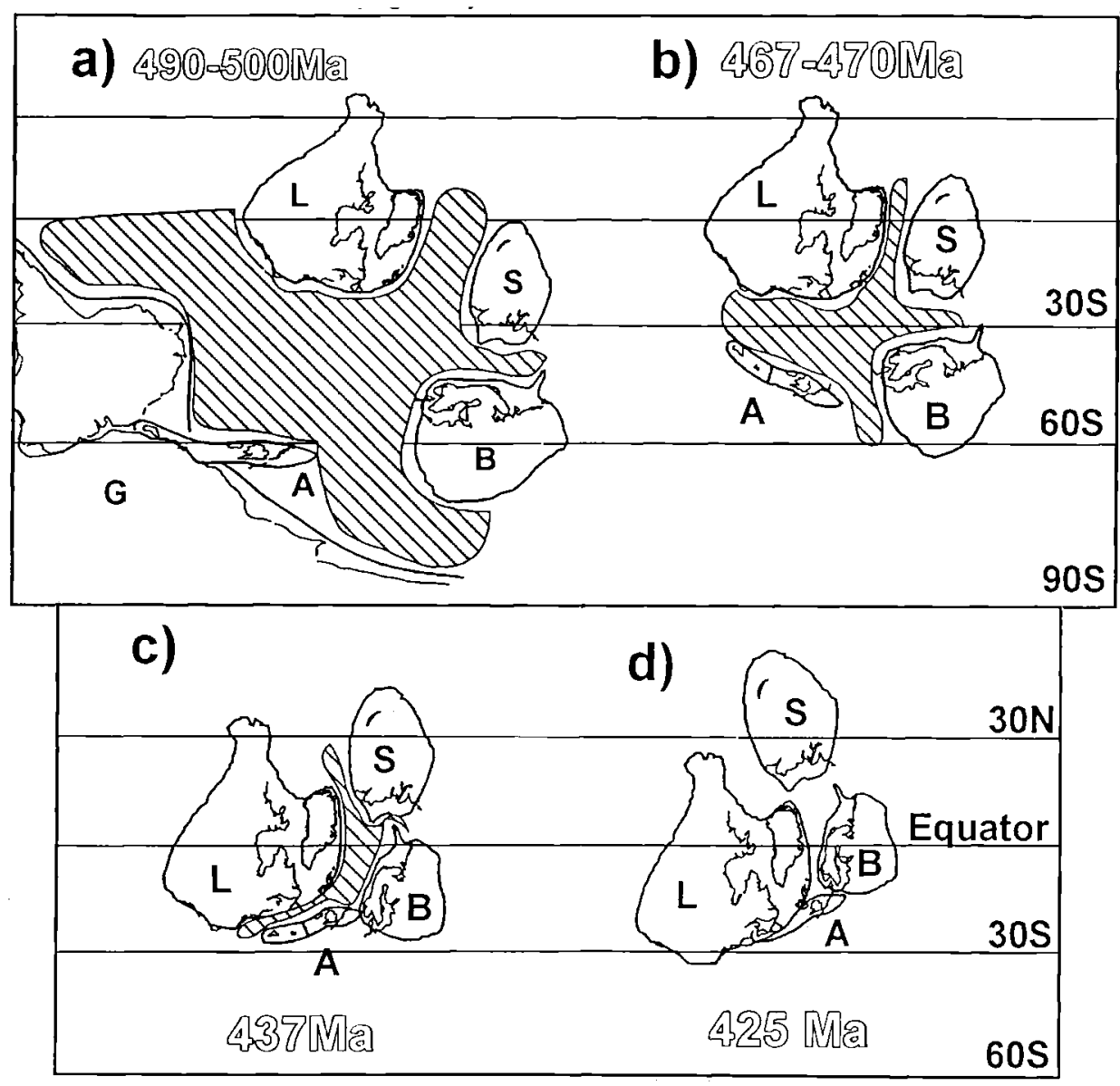

Fig. 1. Lower Ordovician to Mid-Silurian reconstructions for Gondwana (G), Baltica (B), Siberia $(S)$, Laurentia (L), and Avalonia (A). a) Early Ordovician: The Caledonian margin of Baltica is facing northern Siberia. Latest Cambrian to Early Ordovician subduction and Early Ordovician obduction occurs between Baltica and Siberia. Avalonia forms part of Gondwana. b) Early-Middle Ordovician: Avalonia has rifted off Gondwana and the Tornquist Sea between Baltica and Avalonia is gradually closing by subducting oceanic crust beneath Avalonia [Noble et al., 1993]. c) Late Ordovician: Avalonia has joined Baltica. Baltica and Avalonia have undergone substantial counterclockwise rotation while narrowing the oceanic tract between Baltica and Siberia. This rotation may have given rise to deep-seated strike-slip faults that influenced and possibly controlled the generation and ascent of Late Ordovician calc-alkaline granitoids. d) Mid Silurian: Oblique collision of Laurentia and Balonia (Baltica and Avalonia) producing the early Scandian Orogeny. The paleoposition of Siberia is uncertain at this time; we have merely indicated a likely position north of Laurentia and Balonia.

by D. G. Gee and B. A. Sturt, 379 pp., John Wiley, New York, 1985

Mork, M. B. E., K. Kullerud, and A. Stabel, Sm-Nd dating of Seve eclogites, Norrbotten, Sweden-Evidence for early Caledonian (505 Ma) subduction, Contrib. Mineral. Petrol., $99,344,1988$

Noble, S. R., R. D. Tucker, and T. C. Pharaoh,

Lower Palaeozic and Precambrian igneous rocks from eastern England, and their bearing on late Ordovician closure of the Tornquist Sea: Constraints from U-pb and $\mathrm{Nd}$ isotopes, Geol. Mag., 130(6), 833-846, 1993.

Nordgulen, O., The Caledonian Bindal Batholith: Regional setting based on geological, geochemical and isotopic data, Ph.D. thesis Dept. of Geology, University of Bergen, Bergen, Norway, 1993.
Roberts, D., and D. G. Gee, An introduction to the structure of the Scandinavian Caledonides, in The Caledonide Orogen---Scandinavia and Related Areas, edited by D.

G. Gee and B. A. Sturt, pp. 55--68, John Wiley, New York, 1985.

Sturt, B. A., and D. Roberts, Tectonostratigraphic relationships and obduction histories of Scandinavian ophiolithic terranes, in Ophiolite Genesis and Evolution, edited by $\mathrm{K}$. Peters et al., $745 \mathrm{pp}$., Kluwer Academic, Hingham, Mass., 1991

Torsvik, T. H., M. A. Smethurst, R. Van der Voo, A. Trench, N. Abrahamsen, and E. Halvorsen, Baltica: A synopsis of Vendian-Permian paleomagnetic data and their paleotectonic implications, Earth Sci. Rev., 33, 133, 1992. 